\title{
構成刃先が生成する切削速度域における 低合金鋼の切削抵抗
}

\author{
山本 重男*・中島 宏興*2・宮地 博文*
}

Cutting Force of Low Alloy Steels in the Cutting Speed Range in which a Built-up Edge Forms Shigeo Yамамото, Hirooki Nakajima and Hirobumi MiYaJI

Synopsis : A method for estimating the cutting force was studied on the low alloy steels machined with the cutting speed which formed a built-up edge.

At first, the width of the chip shear region(Ws) and the tip radius of the built-up edge(Br) were measured with a micro-machining device. The correlation of them with the hardness of work materials $(\mathrm{H})$ and the cutting speed(V) was obtained.

In the second place, the deformation resistance of the chip shear region (Kfs) and that of the built-up edge(Kfb), which were obtained by the analysis of the previous experimental results, were also correlated with $\mathrm{H}$ and $\mathrm{V}$.

Multiple regression analysis was applied between the components of cutting force and the five factors of $\mathrm{Br}$, Ws, $\mathrm{Kfs}$, $\mathrm{Kfb}$ and microstructual one. It gave the equations to estimate the cutting forces(principal force, side force and thrust force) from $\mathrm{H}$ and $\mathrm{V}$. A good correlation was found between the calculated and the measured values.

Key words : low alloy steel ; machinability; cutting force; chip shear region; built-up edge ; deformation resistance ; multiple regression analysis.

\section{1. 緒言}

鋼の切削加工において，切削工具に加わる抵抗值は工具 寿命や切りくず生成機構の観点から重要である。このため, 切削部の幾何学的な解析結果から, 構成刃先の消滅した切 削速度域を中心として, 切削抵抗の算出式が導かれている ${ }^{1) 2}$ 。

ここでは構成刃先が生成する切削速度域を中心とした切 削抵抗について検討することとした。このため切削抵抗に 大きな影響を及ぼすと思われる 1) 切りくずせん断領域の 幅 (Ws)， 2 ) 構成刃先の先端半径 $(\mathrm{Br}), 3$ ) 切りくずせん 断領域の変形抵抗値 $(\mathrm{Kfs}), 4)$ 構成刃先先端領域の変形抵 抗值 $(\mathrm{Kfb})$, , 4 因子に加えて, 被削材のミクロ組織 $(\mathrm{mS})$ を表わす因子に注目した。

まず，新しい方法によってWsを測定した。その原理およ び測定装置について述べる。並行して顕微鏡観察によりBrを 測定した。次いで，KfsおよびKfbについては著者らが先に 行った実験結果3を用いて算出した。さらに,これら4因子 を被削材の硬さ $(\mathrm{H})$ および切削速度 $(\mathrm{V})$ と関連づけることに より，HおよびVから切削抵抗を算出することを試みた。な お，構成刃先が消滅した切削速度域においても，従来の実 験結果 ${ }^{3) 4}$ である切りくずせん断角 $(\phi)$, 切りくず裹面の変形 流動層 $(\mathrm{F} \mu)$ および $\mathrm{mS}$ より切削抵抗の算出式を導いた。

\section{2. 実験方法}

\section{$2 \cdot 1$ 被削材の組成と切削部の採取}

硬さが広範囲に変化している被削材について切削抵抗を 算出する必要から，ミク口組織の異なるSCM435鋼を被削材 として用いた。Table 1 に被削材の組成と熱処理条件, 硬さ を示した。

切りくずせん断領域の開始および終了域の測定に用いた 切削部は，旋盤に取り付けた特殊刃物台 (急停止装置) を用 いて採取した5)。すなわち, 切削中に切削速度を上回る速度

Table 1. Chemical composition and heat treatment of work materials.

Chemical composition of work material. (mass\%)

\begin{tabular}{ccccccc}
\hline $\mathrm{C}$ & $\mathrm{Si}$ & $\mathrm{Mn}$ & $\mathrm{P}$ & $\mathrm{S}$ & $\mathrm{Cr}$ & $\mathrm{Mo}$ \\
\hline 0.35 & 0.25 & 0.78 & 0.018 & 0.023 & 1.12 & 0.16 \\
\hline
\end{tabular}

Heat treatment conditions and hardness.

\begin{tabular}{lcc}
\hline Work materials $(\phi: 60 \mathrm{~mm}, \ell: 300 \mathrm{~mm})$ & \multicolumn{2}{c}{ Hardness $(\mathrm{HV} 30)$} \\
\hline Annealed & $1123 \mathrm{~K} \cdot 1.5 \mathrm{~h} \rightarrow \mathrm{F} . \mathrm{C}$ & 168 \\
\hline Normalized & $1113 \mathrm{~K} \cdot 1.5 \mathrm{~h} \rightarrow$ A.C, $923 \mathrm{~K} \cdot 2.5 \mathrm{~h} \rightarrow$ A.C & 204 \\
\hline Spheroidized & $(1033 \mathrm{~K} \cdot 3 \mathrm{~h} \rightarrow \mathrm{F} . \mathrm{C} \rightarrow 983 \mathrm{~K} \cdot \mathrm{h}) \times 4$ Times $\rightarrow$ F.C & 158 \\
\hline Quench \& Tempered $1113 \mathrm{~K} \cdot 1 \mathrm{~h} \rightarrow \mathrm{W} . \mathrm{Q}, 873 \mathrm{~K} \cdot 1.5 \mathrm{~h} \rightarrow \mathrm{O} . \mathrm{Q}$ & 305
\end{tabular}


で工具を切削部から離脱させることで，切りくずが生成中 の切削部㕝採取した。さらに，樹脂に埋込んだ状態で切り くず幅の中央断面を研磨して切りくずせん断領域測定用の 試料とした。なお，切削部を採取する際の切込深さは $1.5 \mathrm{~mm}$ で工具送り量は $0.2 \mathrm{~mm} / \mathrm{rev}$, 切削速度は 0.33 よび $1.0 \mathrm{~m} / \mathrm{s}$ で行った。

\section{$2 \cdot 2$ 切りくずせん断領域の幅 (Ws) の測定法}

まず, 切りくずせん断領域の測定原理をFig. 1 に示した。 Fig. 1 (a) は急停止装置を用いて採取した切削部を微小切削 している模式図であり， $\mathrm{s}$ おび $\mathrm{e}$ 線で囲まれた切りくずせ ん断領域を想定した。切削部を矢印の方向に微小切削した 場合, 微小切削工具に加わる切削抵抗はFig. 1 (b)の上うに 切りくずせん断領域の開始するs 点まで法被削試料の硬さに 対応し,切りくずせん断領域が終了したe点からは加工硬化 した切りくずの硬さに対応して変化すると考えた。従って, $\mathrm{s}$ 点からe点までの勾配部分を切りくずせん断領域と及なす ことが出来る。

次いで, Fig. 2 は切りくずせん断領域を測定するために試 作した微小切削装置である。X軸とY軸上に切りくずせん断 領域の測定用試料が取付けられている。軸には歪みゲージ 方式の工具動力計が組込まれ，之の先端に切削工具が付い ている。切削方式は形削盤と似てはいるが，この場合，測 定用試料が移動する。なお，測定用試料には切削方向への

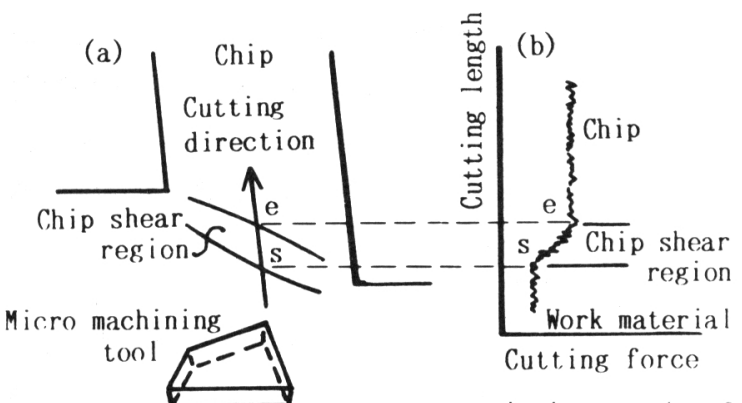

Micro machining of cutting part extracted by quich stop device

variation cutting forc in micro machining.

Fig. 1. Micro-machining method of cutting region and variation of micro-machining force.

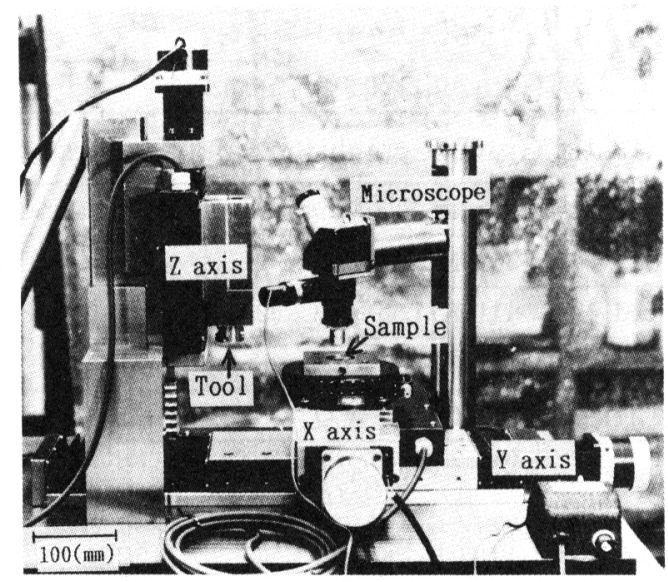

Fig. 2. Micro-machining device.

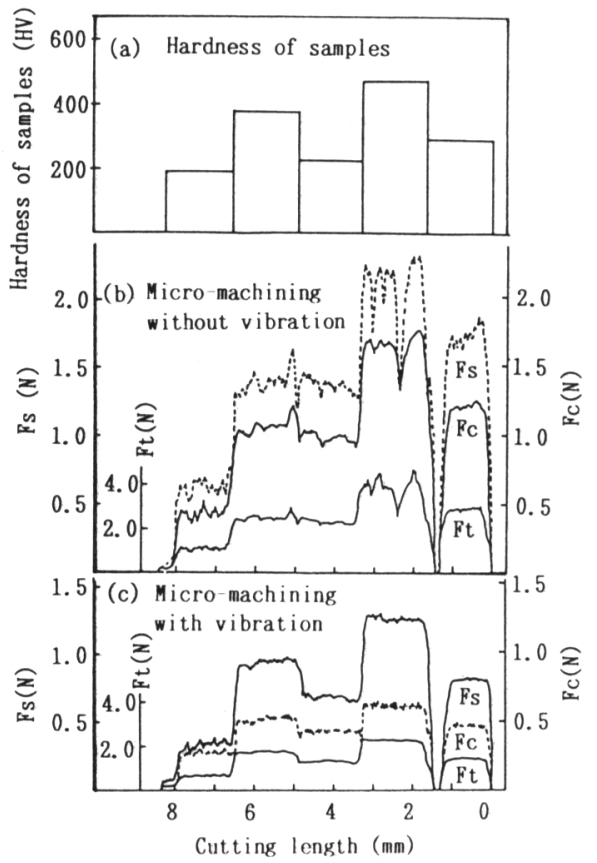

Fig. 3. Relation between hardness of samples and cutting force during micro-machining.

振動(振幅： $8 \mu \mathrm{m}$, 振動数： $50 \mathrm{~Hz}$ ) 党与元る装置が取付け 可能である。各軸の速度と位置決めはプログラムコントロ 一ラからのパルス信号によるステッピングモータの回転で 制御される。そして, 切削面を観察するための光学顕微鏡 ( 〜 400倍) を備えている。

切削工具注超硬K10であるが,ダイヤモンド砥石で入念に 仕上げた場合でも切刃部にはWC粒子に相当する刃こぼれが 認められた。さらに, ダイヤモンド微粒子と樹脂を混和さ せたダイヤモンドシートで研磨して刃こぼれの無い切刃部 在得た。

Fig. 3 は微小切削の条件を選択するために行なった実験結 果である。硬さがHV190〜 470まで異なる試料をFig. 3 (a) の順序で並べて微小切削した際，試料に振動を加えない場 合 (Fig. 3 (b)) と加えた場合 (Fig. 3 (c)) の抵抗線図である。 切削条件は切込深さ (Dc) $10 \mu \mathrm{m}$, 工具送り量 (f) $5 \mu \mathrm{m} /$ ス卜 ローク，工具形状は前报よび横すくい角 $-5^{\circ}$, 前抽よび横 逃げ角 $5^{\circ}$, ノーズ半径 $0.015 \mathrm{~mm}$ であり, 非切削工程では工

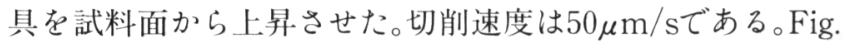
3 (b)で感度の良い送り分力 $(F s)$ を見ると, まず, 最も硬 い試料(右から 2 番目) を切削中の抵抗值怯大きく变動して いる。また，抵抗値が試料の硬さに対応していない。すな わち, 右から 1 番目， 3 番目そして 4 番目の試料では硬さ がそれぞれ異なるが抵抗值は硬さに対応していない。これ に対して, Fig. 3 (c) 法切削方向に振幅 $8 \mu \mathrm{m}$, 周波数 $50 \mathrm{~Hz}$ の振動を試料に加えた場合である。全体的に試料の硬さに 対応した切削抵抗を示しており，同一試料を切削中の抵抗 值の変動も少ない。

ここで，振動を加えることによって被削材の硬さと対応 した切削抵抗が得られる原因について検討してみた。 
まず, 振動なしの切削では被削材の硬さ $(\mathrm{H})$ が増すほぼ切

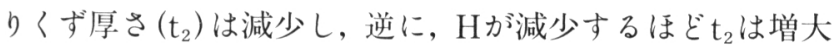
する傾向が予想される。このため, 切削抵抗は $\mathrm{H} に$ 対応しな いものであろう。

振動を加えた場合，切りくずせん断域においては微視的 塑性変形の繰返しを受け，転位の増殖が著しい。一方，工 具一切りくず接触域においては非切削過程で, 切削部の弾 性回復によって切りくずはその流出方向に微小移動し, こ の分, 次の切削過程では工具すくい面を擦過する切りくず の移動量が減少し, 結果としてこの領域の摩擦係数が減少 することが示唆された。

このように, 微小振動切削においては切りくずせん断領 域と工具一切りくず接触領域の関連は薄れ $t_{2}$ は $\mathrm{H}$ に依存し難 くなる。硬さと対応した切削抵抗は主に切りくずせん断領 域の変形挙動に原因すると思われた。

\section{3. 実験結果}

\section{$3 \cdot 1$ 切りくずせん断領域の幅 (Ws) および構成刃先の}

\section{先端半径 $(\mathrm{Br})$ の測定}

Fig. 4 は球状化材を切削速度 $0.33 \mathrm{~m} / \mathrm{s}$ と $1 \mathrm{~m} / \mathrm{s}$ で切削した ときの切りくず生成状態と切りくずせん断領域の開始およ び終了域を示したものである。Fig. 4 (a)においては構成刃 先の前方で切りくずせん断領域の開始位置が湾曲している。 終了線は構成刃先と切りくずとなったばかりの表面側を結 ぶ形となっている。Fig. 4 (b)においては0.33m/sより終了 線が切りくずの流出方向に移行している。その結果, 切り くずせん断領域の幅は切削速度 $0.33 \mathrm{~m} / \mathrm{s}$ より $1 \mathrm{~m} / \mathrm{s} て ゙$ 拡張さ
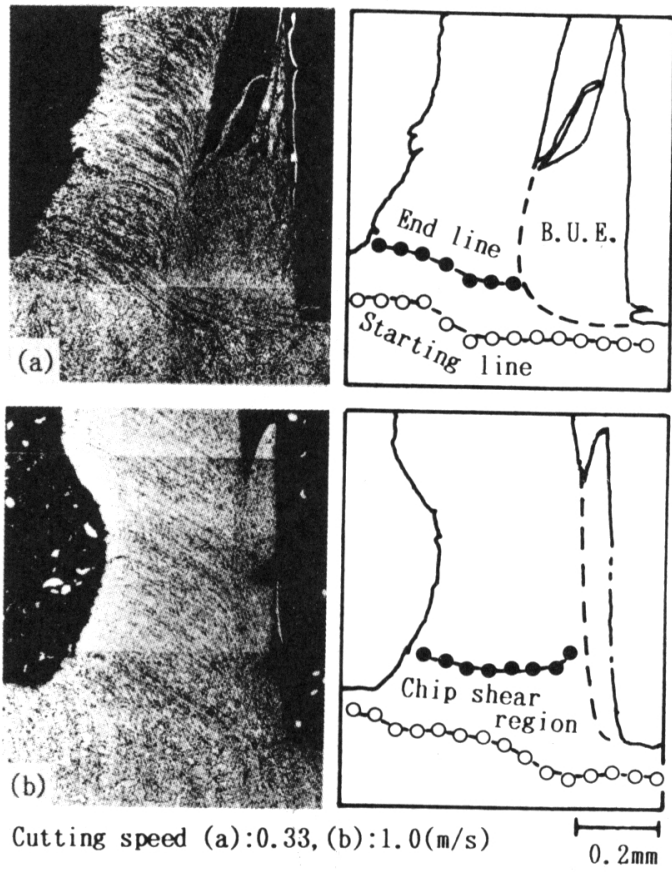

Cutting speed (a):0.33, (b):1.0(m/s)

Fig. 4. Chip shear region of spheroidized samples
measured by micro-machining device (B.U. E : built-up edge).
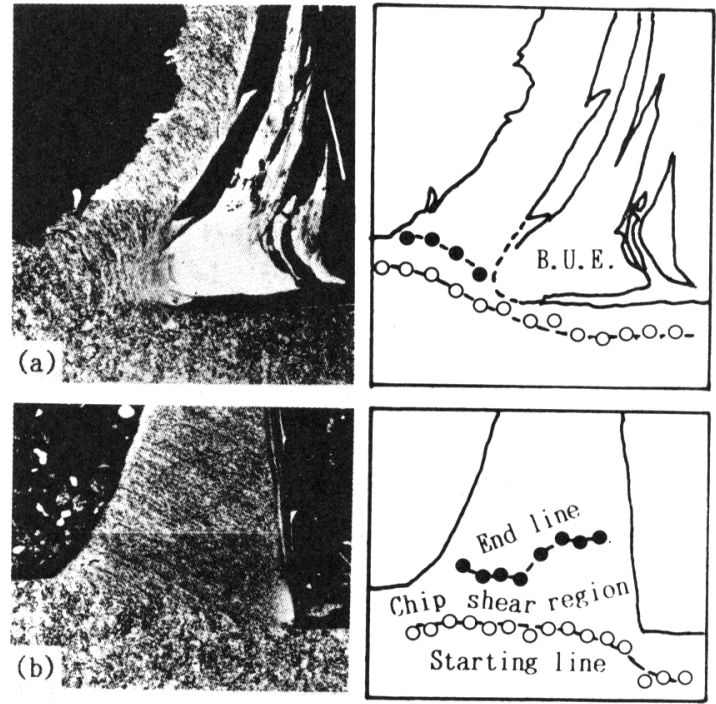

Cutting speed (a):0.33, (b):1.0(m/s)

$0.2 \mathrm{~mm}$

Fig. 5. Chip shear region of quench \& tempered sample measured by micro-machining device.

れている。

Fig. 5 は焼入・焼戻し材の場合であり, Fig. 5 (a)の切削 速度 $0.33 \mathrm{~m} / \mathrm{s}$ においては, 先端半径の小さい構成刃先が生成 していることに原因して, 球状化材に比べ切りくずせん断 領域の幅が狭められている。しかし, Fig. 5 (b)の切削速度 $1 \mathrm{~m} / \mathrm{s}$ にいては, 構成刃先は消滅し, せん断領域の終了域 が切りくず流出方向に大きく移行し, せん断領域の幅が拡 大されている。この他, 焼ならし材についても同様な方法 で切りくずせん断領域を測定した。

Fig. 6 に切りくずせん断領域の平均幅 (Ws：せん断領域 の開始および終了線の間) と光学顕微鏡支用いて測定した構 成刃先の先端半径 $(\mathrm{Br})$ の関係を示した。全体的に相関を示 している。ここで，BrおよびWsを被削材の硬さ $(\mathrm{H} ： \mathrm{HV})$ および切削速度 $(\mathrm{V}: \mathrm{m} / \mathrm{s})$ との関連で重回帰分析し, 次式 が得られた。

$$
\begin{aligned}
& \mathrm{Br}=107-0.21(\mathrm{H})+66.1(\mathrm{~V}) \\
& \mathrm{Ws}=95-0.21(\mathrm{H})+122.4(\mathrm{~V})
\end{aligned}
$$

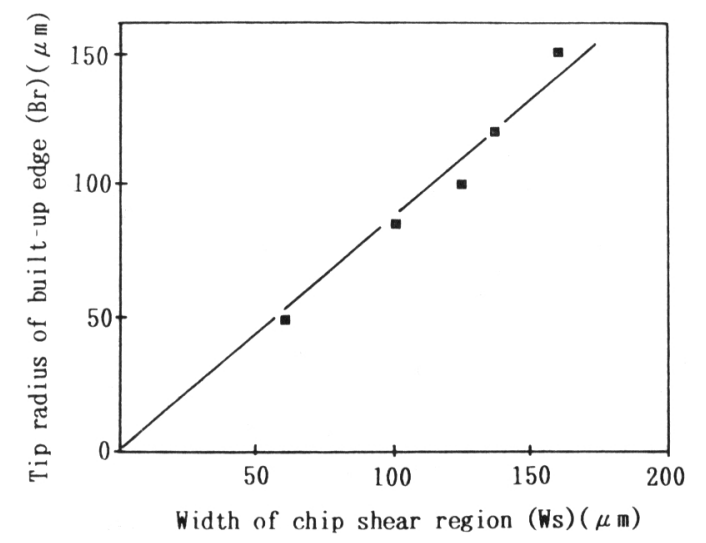

Fig. 6. Relation between width of chip shear region and tip radius of built-up edge. 
(1)（2）式はデータ数が少なく相関係数の検定において有 意水準 $(\alpha) 5 \%$ 有意ではなかった。（以後 $\alpha=1 \%$ 有意 の場合は $\alpha^{*}, 5 \%$ 有意は $\alpha^{* *}$ を用いる)。次に, 重回帰式の あてはまりの良さを表わす重相関係数Rは（1）（2）式につい てそれぞれ0.888および0.894であり, 自由度修正した重相

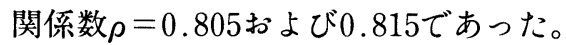

\section{$3 \cdot 2$ 切削域における变形抵抗値}

球状化材, 焼ならし材, そして, 焼入 - 焼戻し材の各切 削抵抗分力の平均值をFig. 7 として示した。なお, 焼なまし 材の切削抵抗值は焼ならし材に近似しているため省略した。 Fig. 7 (a)の球状化材においてはFsのピークが焼ならし材 (Fig. 7 (b)) ほど大きくはなく, 主分力 $\left(\mathrm{Fc}_{\mathrm{C}}\right)$ は切削速度の増 加に伴って減少している。焼入・焼戻し材はFig. 7 (c) に見 るように切削抵抗のピークが球状化材および焼ならし材に 比較して低速切削域に移行している。

このような切削抵抗分力の変化は, 鋼の青熱脆性に関連 づけて説明される構成刃先の生成状態などに原因するもの であろう6)。本実験で用いたと同等な被削材の組成およびミ ク口組織の鋼の青熱脆性については, 切削の際の歪み速度・ 温度に近似した条件で圧縮試験が行われ変形抵抗值 $(\mathrm{Kf})$ と して示されている3)(Fig. 8)。

Fig. 8 より,構成刃先が生成する切削速度域における切削

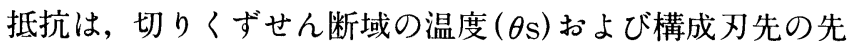
端領域の温度 $(\theta \mathrm{b})$ における被削材の变形抵抗值 $(\mathrm{Kf})$ と密接 に関連していると思われた。この場合の $\theta \mathrm{b} は$, 工具一切り くず(仕上面) 接触界面温度 $(\theta \mathrm{f})$ に近似すると考えられる。 著者らは代表的なミク口組織のSCM435鋼について,工具一 切りくず熱電対法により構成刃先が生成する領域の切削温 度 $(\theta \mathrm{f})$ およ゙切りくずの酸化色から切りくずせん断領域の 温度 $(\theta \mathrm{S})$ をそれぞれ測定した3)。これらの結果を被削材の硬 さ $(\mathrm{H}: \mathrm{HV})$ および切削速度 $(\mathrm{V}: \mathrm{m} / \mathrm{s})$ について重回帰分析 すると

$$
\begin{aligned}
& \theta \mathrm{f} \fallingdotseq \theta \mathrm{b}=429+0.7(\mathrm{H})+469(\mathrm{~V}) \\
& \theta \mathrm{s}=409+0.74(\mathrm{H})+280(\mathrm{~V}) \cdots
\end{aligned}
$$

(( 3 ) 式は $\alpha^{*}, \mathrm{R}=0.978, \rho=0.975,(4)$ 式は $\alpha^{*}, \mathrm{R}=0.870$, $\rho=0.851$ )が得られた(切削条件, Dc $: 1.5 \mathrm{~mm}, \mathrm{f}: 0.2 \mathrm{~mm} /$

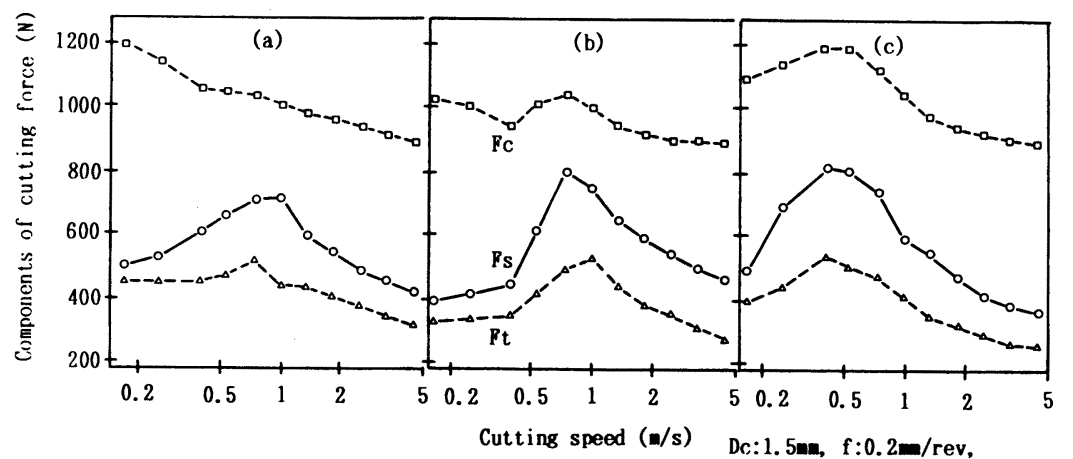

(a) Spheroidized (b) Normalized (c) Quench tempered Tool:K10 $(-6,-6,6,6,15,15,0.8]$

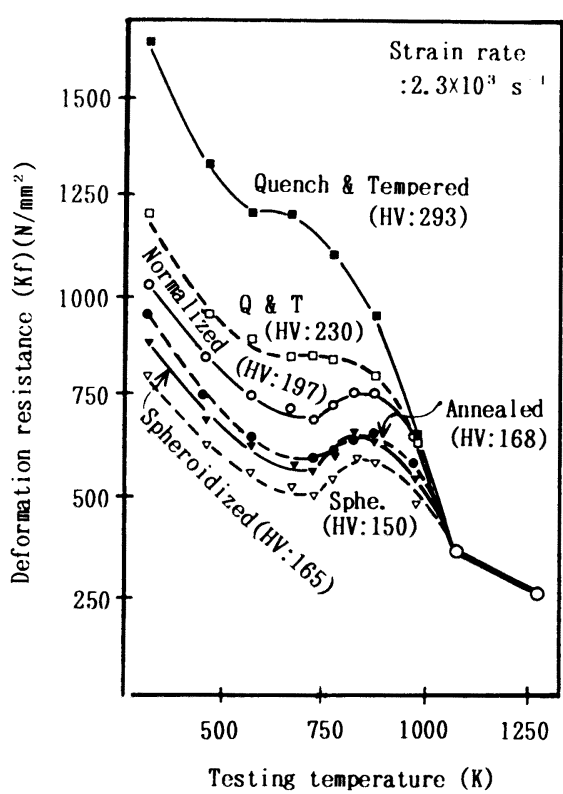

Fig. 8. Deformation resistance of steels with typical micro-structures at various temperatures.

$\mathrm{rev}) 。 こ の$ 際, $\theta$ sは切りくずの酸化色から推定したもので あり, 切削速度 $1 \mathrm{~m} / \mathrm{s}$ 以上では切りくずの冷却効果の影響が 大きくなると思われたので, 切削速度 $0.15 \sim 1 \mathrm{~m} / \mathrm{s}$ 範囲の切

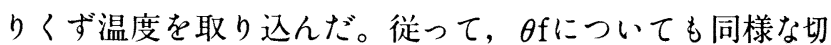
削速度範囲の值を用いた。

ここで, 青熱脆性域を中心とする変形抵抗值 (Kf) はFig. 8 より, 試験温度 $\left(\mathrm{T}: \mathrm{K} \times 10^{-2}\right)$ および被削材の硬さ $(\mathrm{H}$ : $\mathrm{HV})$ との関連で表わすことができる。すなわち $720 \mathrm{~K} に$ 極小 值， $860 \mathrm{~K}$ に極大值をもつ

$$
\mathrm{Kf}\left(\mathrm{N} / \mathrm{mm}^{2}\right)=-3(\mathrm{~T}-6.5)(\mathrm{T}-7.9)(\mathrm{T}-9.3)+\mathrm{kH}
$$

が予想された。 $\mathrm{k}$ は係数であり実測值との関連で 0.36 が得ら れた。

このことから（５）式の試験温度 $(\mathrm{T}) に(3)$ およ゙(4) 式か ら得られる温度を代入することで，切りくずせん断域の変 形抵抗值 (Kfs) および構成刃先先端域における変形抵抗值 (Kfb) をHとVを用いてそれぞれ算出できる。
Fig. 7. Components of cutting force for steels with various heat-treated structures by lathe turning. 


\section{4. 考察}

被削材の硬さ $(\mathrm{H})$ と切削速度 $(\mathrm{V})$ から切りくず生成領域に 関わる 4 因子(切りくずせん断領域の幅 $(\mu \mathrm{m}): \mathrm{Ws}$, 構成刃 先の先端半径 $(\mu \mathrm{m}): \mathrm{Br}$, 切りくずせん断領域の变形抵抗值 $\left(\mathrm{N} / \mathrm{mm}^{2}\right)$ : Kfs, 構成刃先の先端領域の変形抵抗值 $(\mathrm{N} /$ $\left.\mathrm{mm}^{2}\right)$ : $\left.\mathrm{Kfb}\right)$ の推定值を算出し,これらの 4 因子にミクロ組 織 $(\mathrm{mS})$ の因子を加えた ${ }^{778)}$ 。すなわち, 切削部の変形規模 からみて単一組織と見なし得る球化組織および焼入・焼も ぞし組織には 1 の值を, 複合組織である焼きならしおよび 焼なまし組織には 2 の值を用いた。構成刃先が生成する切 削速度域 $(\mathrm{V}: 0.15 \sim 1 \mathrm{~m} / \mathrm{s})$ で実測した切削抵抗分力との 関連を重回帰分析した結果，次式が得られた。

$$
\begin{aligned}
& \mathrm{Fc}=-980+36.7(\mathrm{Br})-19.7(\mathrm{Ws})+1.5(\mathrm{Kfb}) \\
& -0.4(\mathrm{Kfs})-68.8(\mathrm{mS}) \\
& \mathrm{Fs}_{\mathrm{S}}=-1434+24.1(\mathrm{Br})-8.7(\mathrm{Ws})+5.3(\mathrm{Kfb}) \\
& -4.2(\mathrm{Kfs})-60.2(\mathrm{mS}) \\
& \mathrm{Ft}=-335+10.0(\mathrm{Br})-3.6(\mathrm{Ws})+2.3(\mathrm{Kfb}) \\
& -1.9(\mathrm{Kfs})-49.6(\mathrm{mS})
\end{aligned}
$$

(( 6 ) 式は $\alpha^{* *}, \mathrm{R}=0.722, \rho=0.69$ 。( 7 ) 式は $\alpha^{*}, \mathrm{R}=0.899$, $\rho=0.87$ 。（8) 式は $\alpha^{*}, \mathrm{R}=0.789, \rho=0.719$ 。なお,（6 ） 式において, 危険率の最も大きいKfs因子を除き再び重回帰 を行った結果， $\alpha^{*}$ が得られた。)

Fig. 9 に（6)〜（8)式によって算出した切削抵抗分力と実

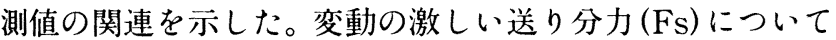
も一応の相関が得られている。

Fig.10は焼ならし材を切削中のFig. 7 (b) から求めた切削

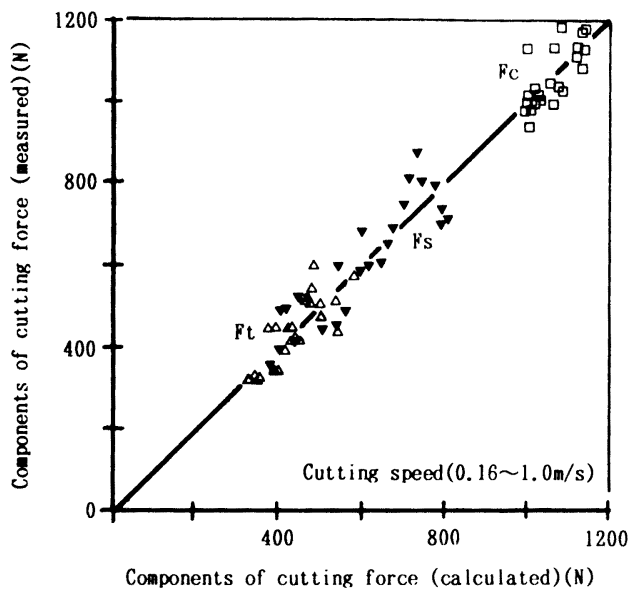

$(\mathrm{PC}=-980+36.7(\mathrm{Br})-19.7(\mathrm{Ws})+1.5(\mathrm{Kfb})-0.4(\mathrm{Kfs})-68.8(\mathrm{mS})$ $\mathrm{Ps}_{\mathrm{S}}=-1434+24.1(\mathrm{Br})-8.7(\mathrm{Ws})+5.3(\mathrm{Kfb})-4.2(\mathrm{Kfs}) \cdot 60.2(\mathrm{mS})$ $\left[\begin{array}{ll}\mathrm{Pt}=-335+10.0(\mathrm{Br})-3.6(\mathrm{Hs})+2.3(\mathrm{Kfb})-1.9(\mathrm{Kfs}) 49.6(\mathrm{mS})\end{array}\right]$

Fig. 9. Components of cutting force (Fc, Fs, Ft) as a function of width of chip shear region (Ws), tip radius of built-up edge $(\mathrm{Br})$, deformation resistance of chip shear region (Kfs) that of tip of built-up edge $(\mathrm{Kfb})$ and factor of micro-structure (mS).

(cutting speed : $0.15 \sim 1 \mathrm{~m} / \mathrm{s}$ )

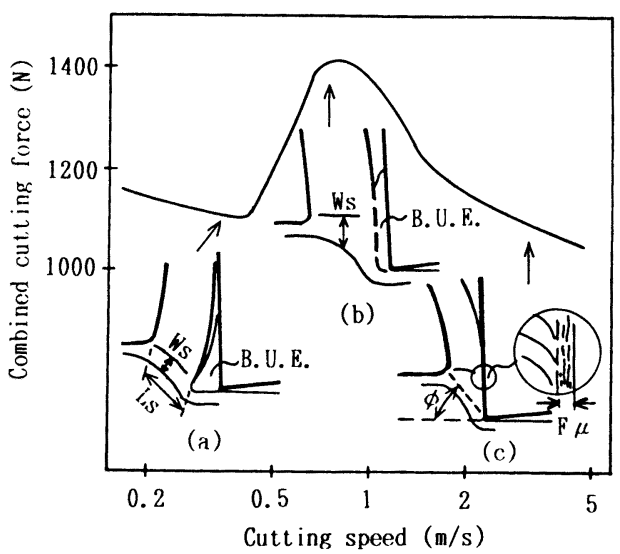

Fig. 10. Schematic diagram of the relation between cutting force and chip shear region at each cutting speed.

抵抗合力 $(\mathrm{R})$ と切りくずせん断領域の幅 (Ws) (Fig. 4 お よ び 5 ) の関係を示した模式困である。Rの極小と極大を示す 切削速度域において，Wsは前者の方が縮小されている。こ のようなWsに加えて,切削抵抗を算出するためには切りく ずせん断領域の面積を求める必要があり切りくず厚さに近 似する切りくずせん断領域の長さ（Fig.10(a)のLs）を求め なければならない。

著者らは構成刃先が消滅した高速切削域において，Fig， 10 (c) に示すような切りくず裏面の変形流動層の厚さ $(\mathrm{F} \mu)$ か 切りくず厚さ (せん断角 $(\phi))$ と良く対応することを示した3)4)。 ここでF $\mu$ は温度の関数である被削材の变形抵抗值 (Kf) に 対応することが判っている。この結果を構成刃先が生成す る切削部に適用すると，切りくずせん断領域の長さ (Ls) は 構成刃先の先端領域の変形抵抗值 $(\mathrm{Kfb}) に$ 依存すると考えら れる。

切削抵抗に及ぼすこれらの諸因子の影響を考えると,Fig. 10 (a)のように, 切削抵抗合力が極小を示す切削速度域にお いては, 構成刃先の先端領域の変形抵抗值 $(\mathrm{Kfb})$ が極小を示 す温度域にあり，このため，工具一切りくず間の見掛け上 の摩擦係数, 構成刃先の先端半径 $(\mathrm{Br})$, 切りくずせん断領 域の幅 $(\mathrm{Ws})$ ，切りくず厚さがそれぞれ減少し，切削抵抗の 極小と結びついたものであろう。これに対して, Fig.10(b) の切削抵抗が極大を示す切削速度域においては，構成刃先 は消滅あるいは薄い平板状となっており，切りくず裏面は 青熱脆性の極大を示す温度域に達していると考えられる。 このため, 摩擦係数, Ws, 切りくず厚さが増して切削抵抗 の極大を引起こしたものであろう。

切削速度1.3〜 $5 \mathrm{~m} / \mathrm{s}$ における切削抵抗分力については, Fig.10 (c) に示す切りくず裹面の変形流動層 $(\mathrm{F} \mu)$ および切り くずせん断角 $(\phi)$ を重要視して ${ }^{3) 4}$, 被削材の硬さ $(\mathrm{H})$ と切 削速度 $(\mathrm{V})$ との関連を求め次式を得た。

$$
\begin{aligned}
& \mathrm{F}_{\mu}(\mu \mathrm{m})=27-0.050(\mathrm{H})-1.30(\mathrm{~V}) \\
& \phi(\mathrm{rad})=0.028+0.00163(\mathrm{H})+0.0373(\mathrm{~V})
\end{aligned}
$$


( ( 9 ) 式は $\alpha^{*}, \mathrm{R}=0.902, \rho=0.892,(10)$ 式は $\alpha^{*}, \mathrm{R}=0.928$, $\rho=0.921)$

このようにして算出したF $\mu$ と 加えて, 切削抵抗分力との関連を重回帰分析して次式を得 た。

$$
\begin{aligned}
& \mathrm{Fc}=-2179+114.5(\mathrm{~F} \mu)+3494.3(\phi)-28.7(\mathrm{mS}) \cdots(11) \\
& \mathrm{Fs}=-6199+245.6(\mathrm{~F} \mu)+7282.4(\phi)+62.7(\mathrm{mS}) \cdots(12) \\
& \mathrm{Ft}=-3857+158.7(\mathrm{~F} \mu)+4569.3(\phi)-7.7(\mathrm{mS}) \cdots(13)
\end{aligned}
$$

（(11） （13) 式は $\alpha *$ 。（11) 式は $\mathrm{R}=0.876, \rho=0.851 ，(12)$ 式はR=0.946, $\rho=0.851 ，(13)$ 式はR=0.93， $\rho=0.916 ） 。$ Fig.11は (11)〜 (13) 式によって算出した切削抵抗分力と実測 值との関連を示したものである。送り分力 $(\mathrm{Fs}) て ゙$ 変動幅が 増しているものの，良い相関が得られた。

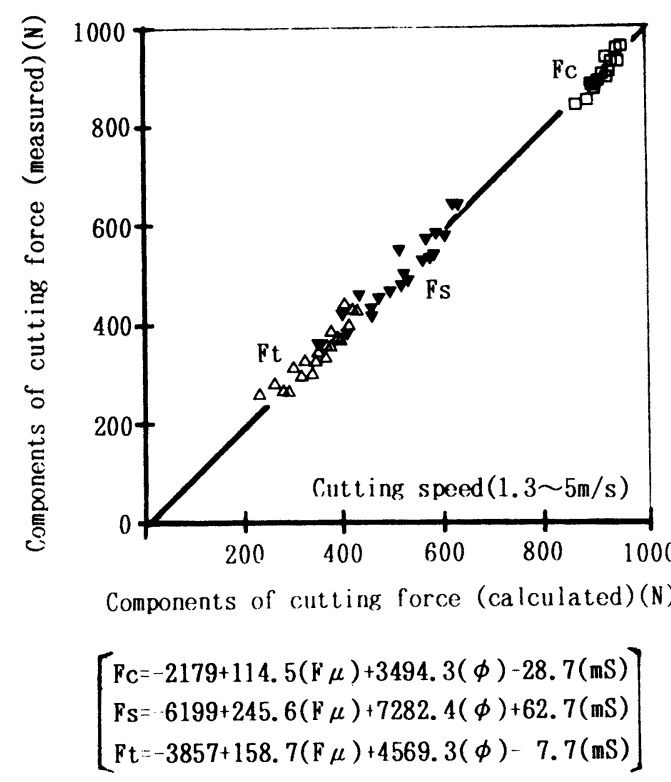

Fig. 11. Components of cutting force (Fc, Fs, Ft) as a function of deformation flow layer $(\mathrm{F} \mu)$, chip shear angle $(\phi)$ and factor of microsturucture $(\mathrm{mS})$. (cutting speed : $1.3 \sim 5 \mathrm{~m} / \mathrm{s}$ )

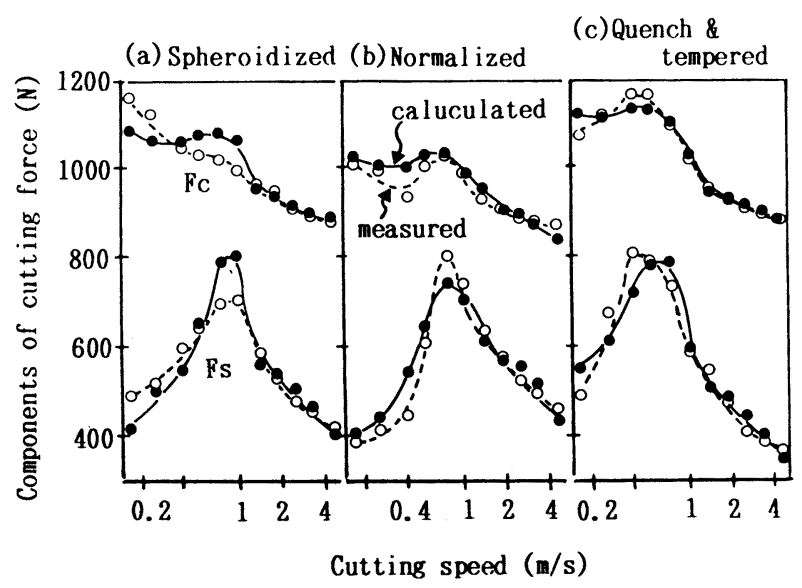

Fig. 12. Comparison of cutting force between measured and calculated.

(cutting speed : $0.15 \sim 5 \mathrm{~m} / \mathrm{s}$ )
Fig.12に構成刃先が生成する切削速度域と消滅した高速切 削速度域における, 切削抵抗の主分力 $\left(F_{C}\right)$ と送り分力 $\left(F_{s}\right)$ の実測值 (平均值：点線) と計算值 (式 (6)〜 ( 7 )および(11) 〜(12) から算出した值：実線）を比較して示した。Fsは構 成刃先の影響を最も強く受けるため变動が激しいにも関わ らず全体的に良い対応を示している。

\section{5. 結言}

代表的なミク口組織をもつ鋼の切削において，被削材の 硬さ $(\mathrm{H})$ および切削速度 $(\mathrm{V})$ から切削抵抗分力を算出する方 法について検討した。この際，切削抵抗に大きな影響を及 ぼすと思われる切削部の変形因子をHおよびVとの関係で算 出し,さらに, ミクロ組織の因子を加え, これらの值と切 削抵抗分力との関連を重回帰分析した。主な結果は次のと おりである。

(1)構成刃先が生成している際の切りくずせん断領域の 開始および終了域を測定するため, 試作した微小切削装置 を用いた。微小切削の際の切削抵抗の变化から切りくずせ ん断領域の幅 $(\mathrm{Ws})$ を測定し，また，顕微鏡観察によって構 成刃先の先端半径 $(\mathrm{Br})$ を求めた。さらに，これらと被削材 の硬さ $(\mathrm{H})$ と切削速度 $(\mathrm{V})$ との関係式を導いた。

(2) 先に行った実験結果3)を用いて,構成刃先先端域にお ける変形抵抗 $(\mathrm{Kfb})$ および切りくずせん断領域の変形抵抗 (Kfs) を $\mathrm{H}$ とから算出する実験式を導いた。これらはWs, $\mathrm{Br}$ おびミクロ組織の因子 $(\mathrm{mS})$ と共に, 実測した各切削抵 抗分力との関連について相関の良い重回帰式を得ることが 出来た。

(3)構成刃先の消滅した高速切削域側において，先に行

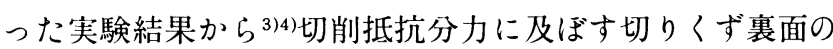
変形流動層 $(\mathrm{F} \mu)$ および切りくずせん断角 $(\phi)$ の影響の大き いことが予想された。被削材の硬さ $(\mathrm{H})$ および切削速度 $(\mathrm{V})$ と $\mathrm{F} \mu$ およ゙ $\phi$ 関係式を導き，さらに，ミクロ組織の因子 $(\mathrm{mS})$ を加えて,これらと実測した各切削抵抗分力との関連 を重回帰分析して良い相関を得た。

終わりに本実験をまとめるにあたり貴重な助言をいただ いた当所・計測解析研究部 田村良雄室長, 千葉大学 吉 田嘉太郎教授に深く感謝いたします。

\section{文献}

1 ） 白井英治，益子正己：日本機械学会論文集，(第 3 部）38 (1972), p. 3255

2 ）中山一雄，新井 実，武井勝男：精密機械， 50 (1984), p.424

3 ) 山本重男, 荒木 透, 金尾正雄: 鉄 と鋼, 65 (1979), p.408

4 ) 山本重男：1991年度精密工学会春季大会, シンポジウム資料, (1991), p.31

5 ）荒木 透，山本重男，内中康夫：鉄 と鋼，54 (1968), p.1912

$6)$ M.C.Shaw, E.Usui and P.A.Smith: Trans. ASME, 83-B (1961), p.181

7 ) 荒木 透, 山本重男 : 精密機械, 42 (1976), p.68

8 ) 山本重男, 荒木 透, 中島宏興：鉄 と鋼， 71 (1985), p.1941 